\title{
Drilling, Construction, Caliper-Log, Aquifer- Test, and Water-Quality Data for Well 8-0437-01, Waiohinu Exploratory Well, Island of Hawaii
}

By Charles J. Ewart

U.S. GEOLOGICAL SURVEY

Open-File Report 98-644

Prepared in cooperation with the

DEPARTMENT OF WATER SUPPLY

COUNTY OF HAWAII 


\section{U.S. DEPARTMENT OF THE INTERIOR \\ BRUCE BABBITT, Secretary}

U.S. GEOLOGICAL SURVEY

Charles G. Groat, Director

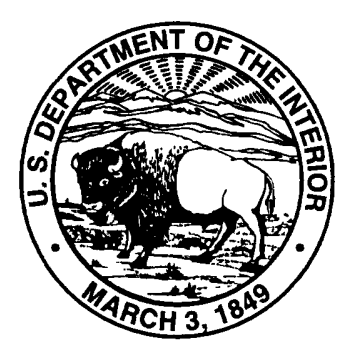

The use of firm, trade, and brand names in this report is for identification purposes only and does not constitute endorsement by the U.S. Geological Survey.

For additional information write to:

District Chief

U.S. Geological Survey

677 Ala Moana Blvd., Suite 415

Honolulu, HI 96813
Copies of this report can be purchased from:

U.S. Geological Survey

Branch of Information Services

Box 25286

Denver, CO 80225-0286 


\section{CONTENTS}

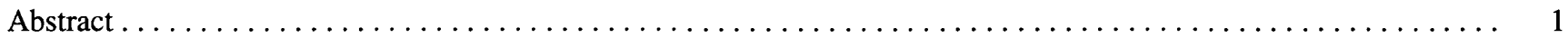

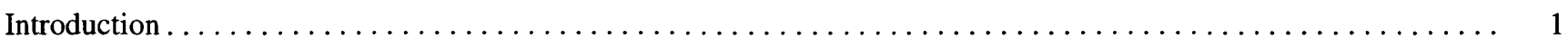

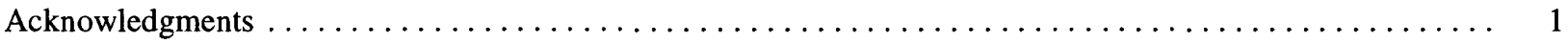

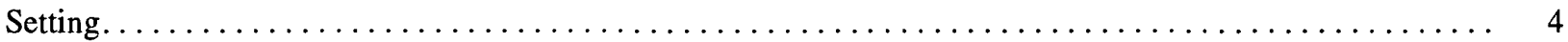

Ground-Water Occurrence. . . . . . . . . . . . . . . . . . . . . . . . . . . . . . . . . . .

Drilling, Construction, Caliper-Log, Geologic-Log, Aquifer-Test, and Water-Quality Data for Waiohinu

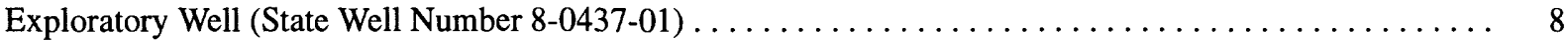

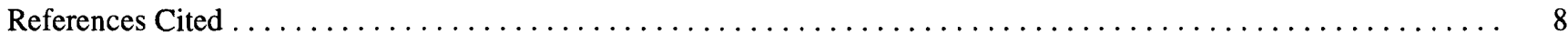

Figures

1-4. Maps showing:

1. The Hawaiian islands, island of Hawaii, and Kau District $\ldots \ldots \ldots \ldots \ldots \ldots$

2. The Waiohinu exploratory well (State well number 8-0437-01), island of Hawaii ...........

3. Generalized geology of the Kau District, island of Hawaii. $\ldots \ldots \ldots \ldots \ldots$

4. Selected wells, shafts, springs, and tunnels, Kau District, island of Hawaii . . . . . . . . . . . . 6

5. Diagram showing construction details of the Waiohinu exploratory well (State well number 8-0437-01),

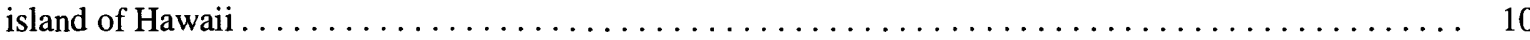

6. Graph showing caliper $\log$ for the Waiohinu exploratory well (State well number 8-0437-01), island of Hawaii . . . . . . . . . . . . . . . . . . . . . . . . . . . . . .

Tables

1. Elevation, water-level, and chloride-concentration data for selected drilled wells in the Kau District,

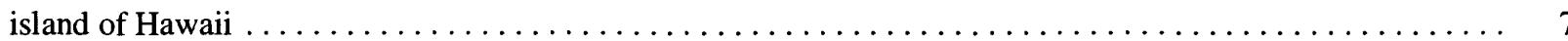

2. Construction data for Waiohinu exploratory well, island of Hawaii. $\ldots \ldots \ldots \ldots$

3. Geologic log for Waiohinu exploratory well (State well number 8-0437-01), island of Hawaii . . . . . . . . . . 12

4. Drillers' $\log$ for Waiohinu exploratory well (State well number 8-0437-01), island of Hawaii. . . . . . . . . . . . 14

5. Aquifer-test data for Waiohinu exploratory well, State well number 8-0437-01, island of Hawaii . . . . . . . . 17

6. Water-quality data for Waiohinu exploratory well, Waiohinu, Hawaii. . . . . . . . . . . . . . . 19

7. Water-quality data for samples collected during the aquifer test at Waiohinu exploratory well

(State well number 8-0437-01), October 1994, island of Hawaii. . . . . . . . . . . . . . . . 20

\section{Conversion Factors}

\begin{tabular}{rll}
\hline Multiply & By & To obtain \\
\hline foot (ft) & 0.3048 & meter \\
gallon (gal) & 3.785 & liter \\
mile (mi) & 1.609 & kilometer \\
inch (in.) & 25.4 & millimeter \\
\hline
\end{tabular}

Elevations in this report are referenced to mean sea level.

Specific conductance is given in microsiemens per centimeter $(\mu \mathrm{S} / \mathrm{cm})$ at 25 degrees Celsius. Microsiemens per centimeter is numerically equivalent to micromhos per centimeter. 


\title{
Drilling, Construction, Caliper-Log, Aquifer-Test, and Water-Quality Data for Well 8-0437-01, Waiohinu Exploratory Well, Island of Hawaii
}

\author{
By Charles J. Ewart
}

\section{Abstract}

The Waiohinu exploratory well (State well number 8-0437-01) was drilled in 1994 about 2,500 feet northwest of the community of Waiohinu. The well is located at a water tank site on County of Hawaii property at an elevation of 1,300 feet. The well, which was drilled into rocks of the Mauna Loa Volcano to a depth of 1,000 feet, encountered a water table at an elevation of 1,016 feet. Well-construction data; geologic, drilling, and caliper logs; and aquifer-test and water-quality data are presented for the well. The well is one of three exploratory wells drilled on the island of Hawaii between September 1994 and April 1995 in cooperation with the County of Hawaii Department of Water Supply.

\section{INTRODUCTION}

The Waiohinu exploratory well was the first of three deep exploratory wells drilled on the island of Hawaii between August 1994 and April 1995. These wells were drilled by the U.S. Geological Survey (USGS) as part of a program of exploratory/monitor well drilling carried out in cooperation with the County of Kauai Department of Water, the County of Hawaii Department of Water Supply, and the City and County of Honolulu Board of Water Supply. The program, begun in 1993, is designed to provide hydrologic and geologic information for aquifers in each of the island counties. This information is vital to the understanding of the ground-water systems on each island and for estimating the amount of available ground water.
In addition to providing needed hydrogeologic information, the exploratory wells completed under this program will be used as long-term monitoring wells to provide data and information for the management, protection, and preservation of the ground-water resources. The rotation of the drilling rig between islands and the duration of drilling on each island are determined by the three county water managers. Drilling sites are prioritized and selected jointly by the county water departments and the USGS.

The purpose of the Waiohinu exploratory well was to provide information on the little known ground-water resources of the western part of the Kau District (fig. 1), which is an area that often has water shortage during times of low rainfall. The well was drilled on County of Hawaii property at an elevation of $1,300 \mathrm{ft}$ above sea level, and about 2,500 ft northwest of the community of Waiohinu (fig. 2). Water was encountered at a depth of $284 \mathrm{ft}$ below land surface $(1,016 \mathrm{ft}$ above mean sea level) and remained at that level for the duration of the drilling. The extent of this high-level water body and the nature of the impounding structures are not known.

This report presents geohydrologic, aquifer-test, and water-quality data, and the construction details of the well.

\section{Acknowledgments}

The USGS gratefully acknowledges the assistance of the Hawaii County Department of Water Supply in site preparation and logistical support throughout the period of well construction and testing. We also acknowledge the cooperation of the Hilo Office, State of Hawaii Division of Land Management and Mr. Walter D. Andrade, landowner and lessee respectively, 


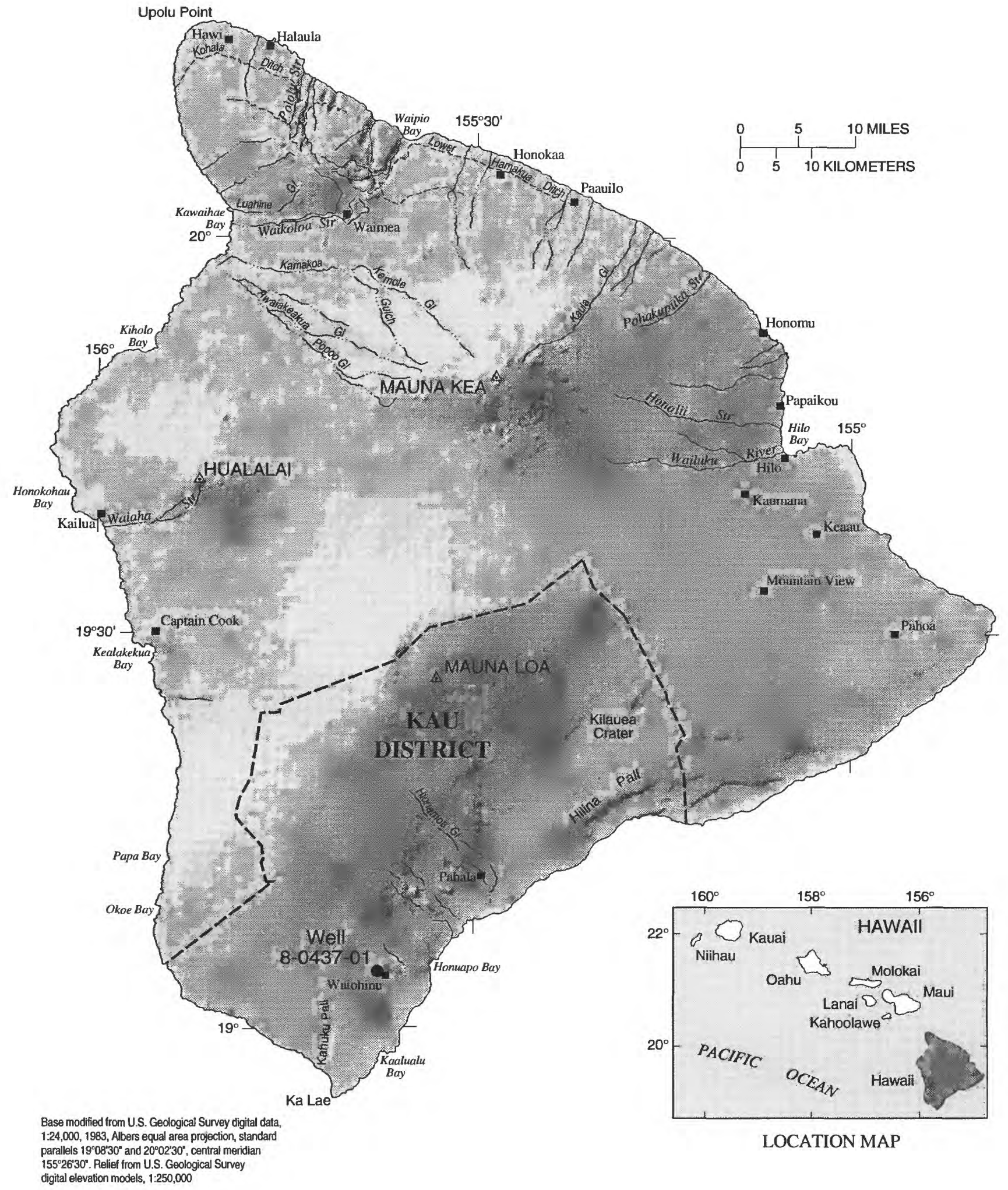

Figure 1. Hawaiian islands, island of Hawaii, and Kau District. 


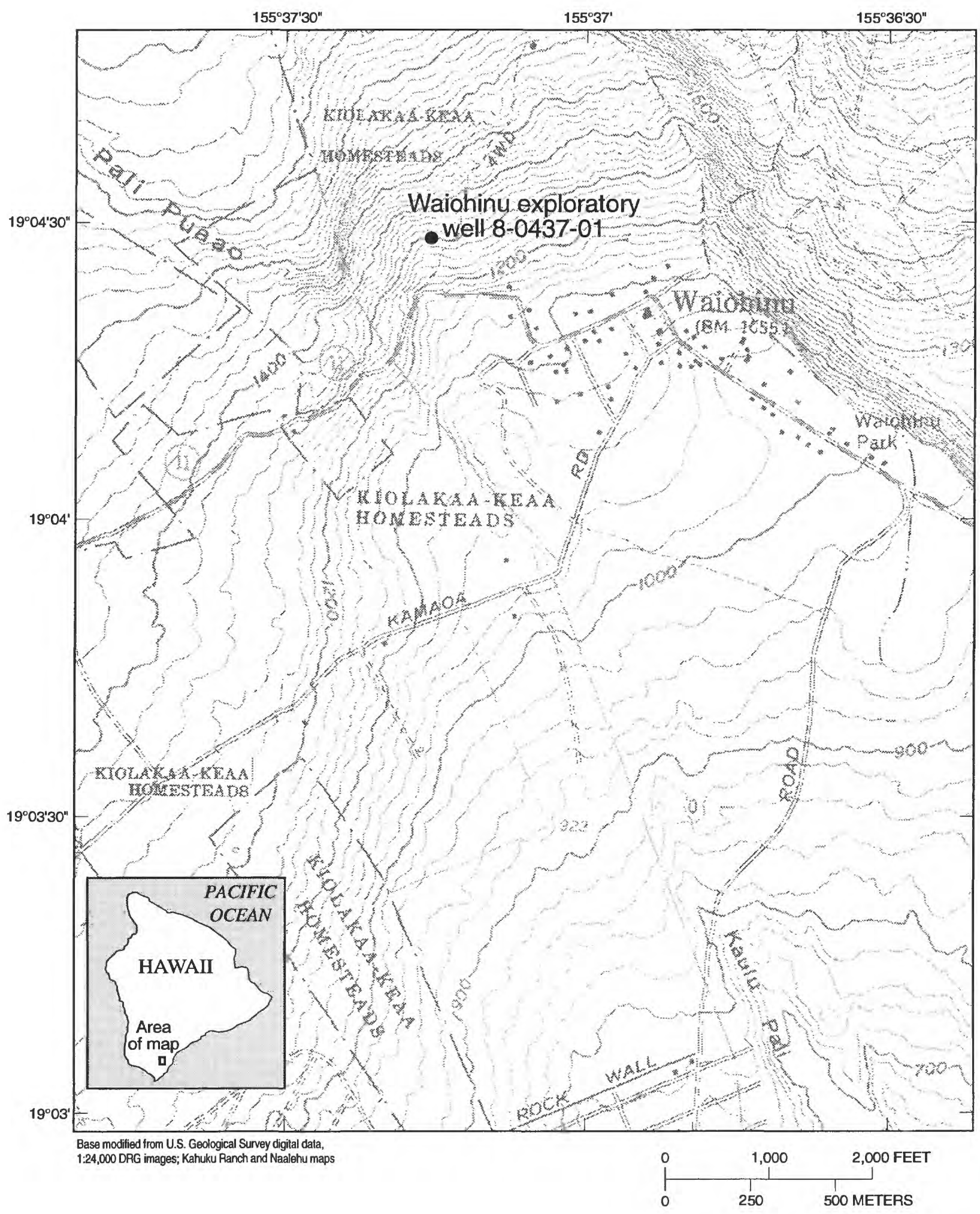

Figure 2. Location of the Waiohinu exploratory well (State well number 8-0437-01), island of Hawaii. 
for allowing the USGS to enter and cross their property to provide access to the drilling site.

\section{Setting}

The Waiohinu exploratory well (State well number 8-0437-01) is located at the Hawaii County Department of Water Supply storage tank just northeast of the community of Waiohinu on the southern slope of Mauna Loa Volcano in the southwestern part of the Kau District of the island of Hawaii (fig. 2). The Kau District is the largest of the island of Hawaii's nine districts and has a land area of almost 625,000 acres. Elevations within the District range from sea level to $13,700 \mathrm{ft}$ at the summit of Mauna Loa. Average annual rainfall within the District ranges from about $20 \mathrm{in}$. at the coast near South Point (Ka Lae) to more than 125 in. at the $3,000 \mathrm{ft}$ elevation between Waiohinu and Pahala and about 100 in. at the summit of Kilauea Volcano.

The Kau District consists of rocks from Mauna Loa Volcano which include lava flows and pyroclastic deposits of three volcanic series and rocks from Kilauea Volcano, which consist of lavas and pryoclastics of two volcanic series (fig. 3). The lavas of the Kau Basalt, which make up most of the District, are highly permeable (Stearns and Macdonald, 1946), and no streams within the Kau District reach the sea except after periods of intense rainfall (Davis and Yamanaga, 1966).

\section{GROUND-WATER OCCURRENCE}

The occurrence of ground water in the Kau District is described in detail by Stearns and Clark (1930), Stearns and Macdonald (1946), and Davis and Yamanaga (1966 and 1973). The following is a generalized summary from these works for that part of the District formed from rocks from Mauna Loa Volcano.

Within the Kau District, ground water is found as basal water, which is a roughly lens-shaped body of freshwater near sea level floating on seawater, and as high-level ground water, which may be impounded by volcanic dikes or other structures or perched on lowpermeability geologic units such as volcanic ash. Recharge to the basal ground-water body is from direct infiltration of rainfall on the permeable land surface, from subsurface discharge of high-level ground-water bodies, and from infiltration of water flowing over permeable rock in stream channels. Recharge to the highlevel ground-water body is from direct infiltration of rainfall. Discharge from the basal water body is from springs and seeps visible at the coast or discharging below sea level offshore. Evidence of substantial ground-water flow at the coast is provided by the large discharge at Ninole and Kawaa Springs (fig. 4). Average discharge from these springs is estimated to range between 30 to $50 \mathrm{Mgal} / \mathrm{d}$.

Chloride-ion concentration is about $100 \mathrm{mg} / \mathrm{L}$ at Kawaa Springs and ranges between 300 to $400 \mathrm{mg} / \mathrm{L}$ at Ninole Springs. Along the coast southwestward from Honuapo to $\mathrm{Ka} \mathrm{Lae}$, the visible ground-water discharge decreases and the salinity of the water increases. A dug well near the shore of Waikapuna Bay yielded water with a chloride-ion concentration of about $2,000 \mathrm{mg} / \mathrm{L}$, and at a dug well near Waipouli the chloride-ion concentration was about $1,800 \mathrm{mg} / \mathrm{L}$. Dug wells and a spring at Kaalualu yielded water with a chloride-ion concentration between 2,000 and 3,000 $\mathrm{mg} / \mathrm{L}$. Highlevel ground water is manifested by the occurrence of springs and seeps primarily between Pahala and Waiohinu at elevations between 2,000 and 5,000 ft. The springs are perched in lava flows by intercalated ash beds. The larger springs were developed by horizontal tunneling along the ash layers during the period 192130 to provide water for sugarcane fluming from upland fields to the sugar mill at Honuapo. The perched water bodies are irregular and discontinuous because of great variations in the permeability and thickness of the ash layers and the discharge from the development tunnels fluctuates with rainfall. Evidence of a high-level body of ground water was discovered in 1946 when a shaft (8-1128-01) designed to develop basal water encountered water at $228 \mathrm{ft}$ above sea level near Pahala. Subsequently the Hawaii County Department of Water Supply drilled an exploratory well (8-1229-01) near Pahala that encountered water standing $384 \mathrm{ft}$ above sea level.

Most recently, the Waiohinu exploratory well encountered high-level ground water standing at 1,016 $\mathrm{ft}$ above sea level. The extent of both of these high-level ground-water bodies and the nature of the impounding structures is not known. A summary of drilled wells in the Kau District compiled from existing records is shown in table 1. 


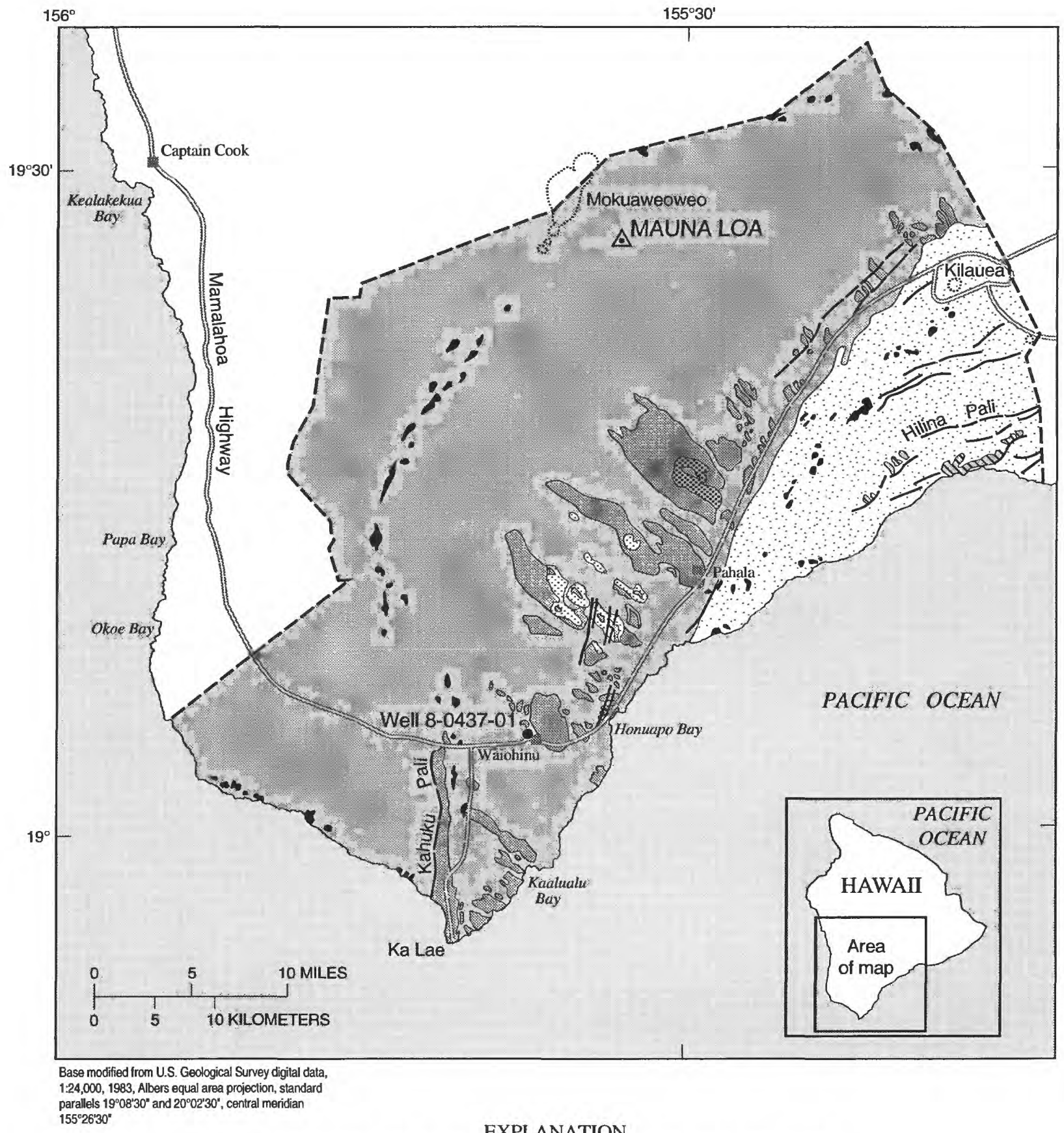

\section{EXPLANATION}

MAUNA LOA VOLCANO

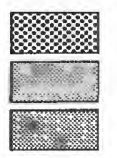

Mud flow of 1868 (recent)

Kau Basalt (Pleistocene)

Kahuku Basalt capped by

Pahala Ash (Pleistocene)

- CINDER AND SPATTER CONES

$\longrightarrow$ FAULT

\section{KILAUEA VOLCANO}

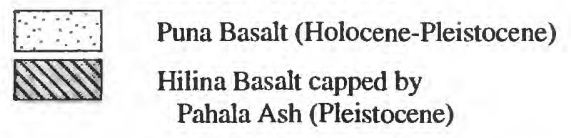

\section{EROSIONAL UNCONFORMITY}

Ninole Basalt (Pleistocene or older)

CRATER

- - KAU DISTRICT BOUNDARY

Figure 3. Generalized geology of the Kau District, island of Hawaii (modified from Stearns and Macdonald, 1946 and Langenheim and Clague, 1987). 


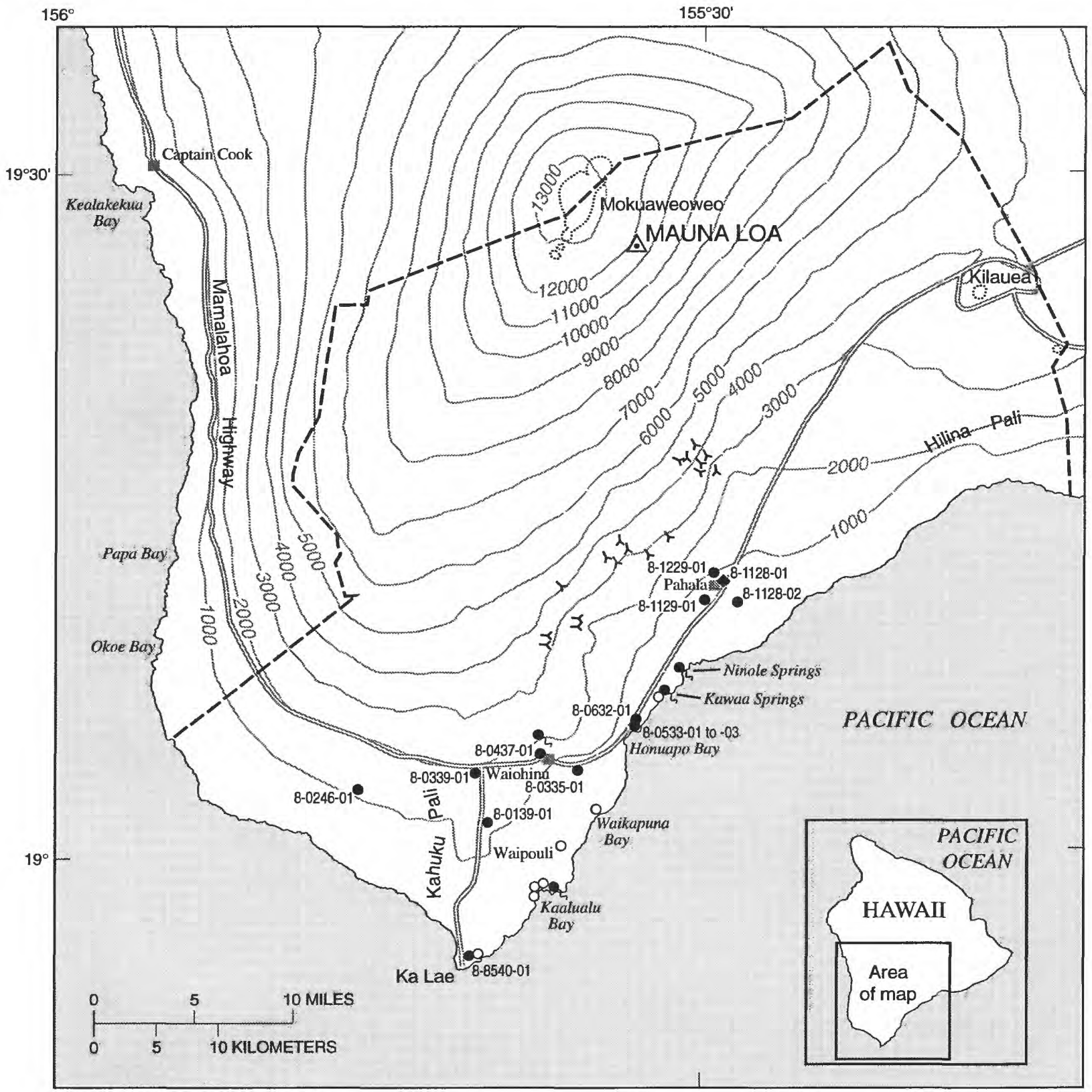

Base modified from U.S. Geological Survey digital data,

1:24,000,1983, Albers equal area projection, standard

parallels $19^{\circ} 08^{\prime} 30^{\prime \prime}$ and $20^{\circ} 02^{\prime} 30^{\prime \prime}$, central menidian

$155^{\circ} 26^{\prime} 30^{\circ}$

\section{EXPLANATION}

\begin{tabular}{|c|c|c|c|}
\hline 8-0437-01 & DRILLED WELL AND NUMBER & t & WATER-DEVELOPMENT TUNNEL \\
\hline 0 & DUG WELL OR WATER HOLE & $-2000-$ & $\begin{array}{l}\text { TOPOGRAPHIC CONTOUR--Interval } \\
1,000 \text { feet }\end{array}$ \\
\hline $8-1128-01$ & SHAFT AND NUMBER & & \\
\hline en & SPRING & 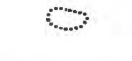 & CRATER \\
\hline & & ---- & KAU DISTRICT BOUNDARY \\
\hline
\end{tabular}

Figure 4. Selected wells, shafts, springs, and tunnels, Kau District, island of Hawaii. 
Table 1. Elevation, water-level, and chloride-concentration data for selected drilled wells in the Kau District, island of Hawaii [Source of data: State of Hawaii Commission on Water Resource Management records, Davis and Yamanaga, 1973, and USGS Hawaii District files; >, greater than; <, less than; --, no data. Datum is mean sea level]

\begin{tabular}{ccccc}
\hline State well number & Year drilled & $\begin{array}{c}\text { Elevation } \\
\text { (feet) }\end{array}$ & $\begin{array}{c}\text { Water level } \\
\text { (feet) }\end{array}$ & $\begin{array}{c}\text { Chloride } \\
\text { concentration } \\
\text { (milligrams per liter) }\end{array}$ \\
\hline $8-0139-01$ & 1990 & 1,259 & 7.2 & 115 \\
$8-0246-01$ & 1982 & 1,049 & 9.5 & $>300$ \\
$8-0335-01$ & 1971 & 745 & 10 & 10 \\
$8-0339-01$ & 1997 & 1,944 & 435 & 5 \\
$8-0437-01$ & 1994 & 1,300 & 1,016 & 1,220 \\
$8-0533-01$ & 1946 & 22 & -- & 580 \\
$8-0533-02$ & 1965 & 94 & 2 & 500 \\
$8-0533-03$ & 1965 & 89 & 3.2 & 500 \\
$8-0632-01$ & 1965 & 103 & 2.9 & 12 \\
$8-1128-01$ & 1947 & 774 & 228 & 650 \\
$8-1128-02$ & 1970 & 304 & 8.7 & 55 \\
$8-1129-01$ & 1974 & 672 & 14 & 7 \\
$8-1229-01$ & 1972 & 1,112 & $<0.5$ & 5 \\
$8-8540-01$ & 1941 & 51 & & 5 \\
\hline
\end{tabular}


DRILLING, CONSTRUCTION, CALIPERLOG, GEOLOGIC-LOG, AQUIFER-TEST, AND WATER-QUALITY DATA FOR WAIOHINU EXPLORATORY WELL (STATE WELL NUMBER 8-0437-01)

The Waiohinu exploratory well was drilled using an air-rotary system with a mixture of air, water, foam, and polymer employed as the drilling fluid to aid in stabilizing the borehole and to remove drill cuttings and water. Samples of drill cuttings were obtained at 5-ft intervals except at those depths where drilling-fluid circulation was lost. Drilling began on September 21, 1994 and was completed on October 23, 1994. A 12-1/4 in. hole was drilled to a depth of $20 \mathrm{ft}$ and an 8-in. insidediameter steel casing was grouted in place. The remainder of the hole was drilled with a 6-3/4 in. tricone tungsten carbide bit. Well-construction data are provided in table 2 and construction details are shown in figure 5.

Drilling was halted on September 26, 1994 at a depth of $452 \mathrm{ft}$ to evaluate the water in the hole. A depth-to-water measurement indicated water standing at $284.82 \mathrm{ft}$ below the top of casing. Bailed samples were obtained and drilling was halted to conduct an aquifer test. A 4-day aquifer test was done and drilling resumed from $452 \mathrm{ft}$. The well was drilled to a total depth of $1,000 \mathrm{ft}$ at which point the air compressor on the drill rig could no longer unload the hole. The depth to water remained at about $284 \mathrm{ft}$ below the top of the casing during the drilling.

A caliper $\log$ (fig. 6) was made after reaching the final depth of $1,000 \mathrm{ft}$. The well was cased with 4-in. inside-diameter, threaded, flush jointed, steel casing. Slotted casing was installed below a depth of $240 \mathrm{ft}$. The total length of casing installed was $972 \mathrm{ft}$ as $28 \mathrm{ft}$ of hole was lost because of caving. A cement basket was installed and a grout seal was placed between the 4-in steel casing and the wall of the drill hole from a depth of $243 \mathrm{ft}$ to the surface. Construction details of the Waiohinu exploratory well are given in table 2 .

Table 3 contains a geologic log of the well and table 4 is the driller's log of the hole. The aquifer-test data are summarized in table 5 and the water-quality data are listed in table 6. Miscellaneous water-quality data for other sources of water in the vicinity of the Waiohinu exploratory well are shown in table 7 , and water-quality data for samples collected during the aquifer test are shown in table 8 .

\section{REFERENCES CITED}

Davis, D.A., and Yamanaga, George, 1966, Preliminary report on the water resources of the Kau District, Hawaii: Hawaii Division of Water and Land Development, Department of Land and Natural Resources, Circular C27, $25 \mathrm{p}$.

Davis, D.A., and Yamanaga, George, 1973, Water resources summary, island of Hawaii: Hawaii Division of Water and Land Development, Department of Land and Natural Resources, Report R47, 42 p.

Langenheim, V.A.M., and Clague, D.A., 1987, The Hawaiian-Emperor volcanic chain, chap. 1 of Decker, R.W., Wright, T.L., and Stauffer, P.H., eds., Volcanism in Hawaii: U.S. Geological Survey Professional Paper 1350 , v. 1, p. 55-84.

Stearns, H.T., and Clark, W.O., 1930, Geology and water resources of the Kau District, Hawaii: U.S. Geological Survey Water-Supply Paper 616, 194 p.

Stearns, H.T., and Macdonald, G.A., 1946, Geology and ground-water resources of the island of Hawaii: Hawaii Division of Hydrography Bulletin 9, 363 p. 
Table 2. Construction data for Waiohinu exploratory well, island of Hawaii [Elevation datum is mean sea level; in., inch; ft., feet; id, inside diameter]

\begin{tabular}{|c|c|}
\hline Well name.......... & Waiohinu Exploratory Well \\
\hline State well number. . . . . . . . . . & 8-0437-01 \\
\hline Latitude and longitude .......... & $19^{\circ} 04^{\prime} 23^{\prime \prime} \mathrm{N}, 155^{\circ} 37^{\prime} 15^{\prime \prime} \mathrm{W}$ \\
\hline Hawaii tax map key number. . . . . . . . . . . & $9-5-005: 002$ \\
\hline Landowner .............. & Hawaii County Department of Water Supply \\
\hline Well completed......... & October 23, 1994 \\
\hline Driller $\ldots \ldots \ldots \ldots \ldots \ldots \ldots \ldots \ldots \ldots \ldots \ldots$ & G. Wayne Heick, USGS \\
\hline Surface hole diameter $\ldots \ldots \ldots \ldots \ldots \ldots \ldots \ldots \ldots$ & $12-1 / 4$ in. \\
\hline Bottom of surface casing $\ldots \ldots \ldots \ldots \ldots \ldots \ldots \ldots \ldots$ & $1,279 \mathrm{ft}$ \\
\hline Surface casing type and diameter $\ldots \ldots \ldots \ldots \ldots \ldots \ldots$ & Steel, 0.188 -in. wall, 8 -in. id \\
\hline Final hole diameter. . . . . . . . . & $6-3 / 4$ in. \\
\hline Bottom of well elevation ........... & $327 \mathrm{ft}$ \\
\hline Inner casing type and diameter $\ldots \ldots \ldots \ldots \ldots \ldots \ldots$ & Steel, solid and slotted, 4-in. id \\
\hline Slotted interval elevations $\ldots \ldots \ldots \ldots \ldots \ldots \ldots \ldots \ldots$ & $1,059 \mathrm{ft}$ to $327 \mathrm{ft}$ \\
\hline Reference mark elevation (bolt in concrete pad) $\ldots \ldots \ldots \ldots \ldots \ldots$ & $1,299.26 \mathrm{ft}$ \\
\hline Measuring point (top of inner casing) elevation. . . . . . . . . . . & $1,299.83 \mathrm{ft}$ \\
\hline Water level and date of measurement. . . . . . . . . . . . & $1,014.44 \mathrm{ft}$, September 26, 1995 \\
\hline 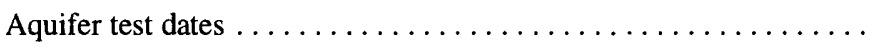 & October 9-13, 1994 \\
\hline Date and time of water sample $\ldots \ldots \ldots \ldots \ldots \ldots \ldots \ldots$ & October $13,1994,1100$ hours \\
\hline
\end{tabular}




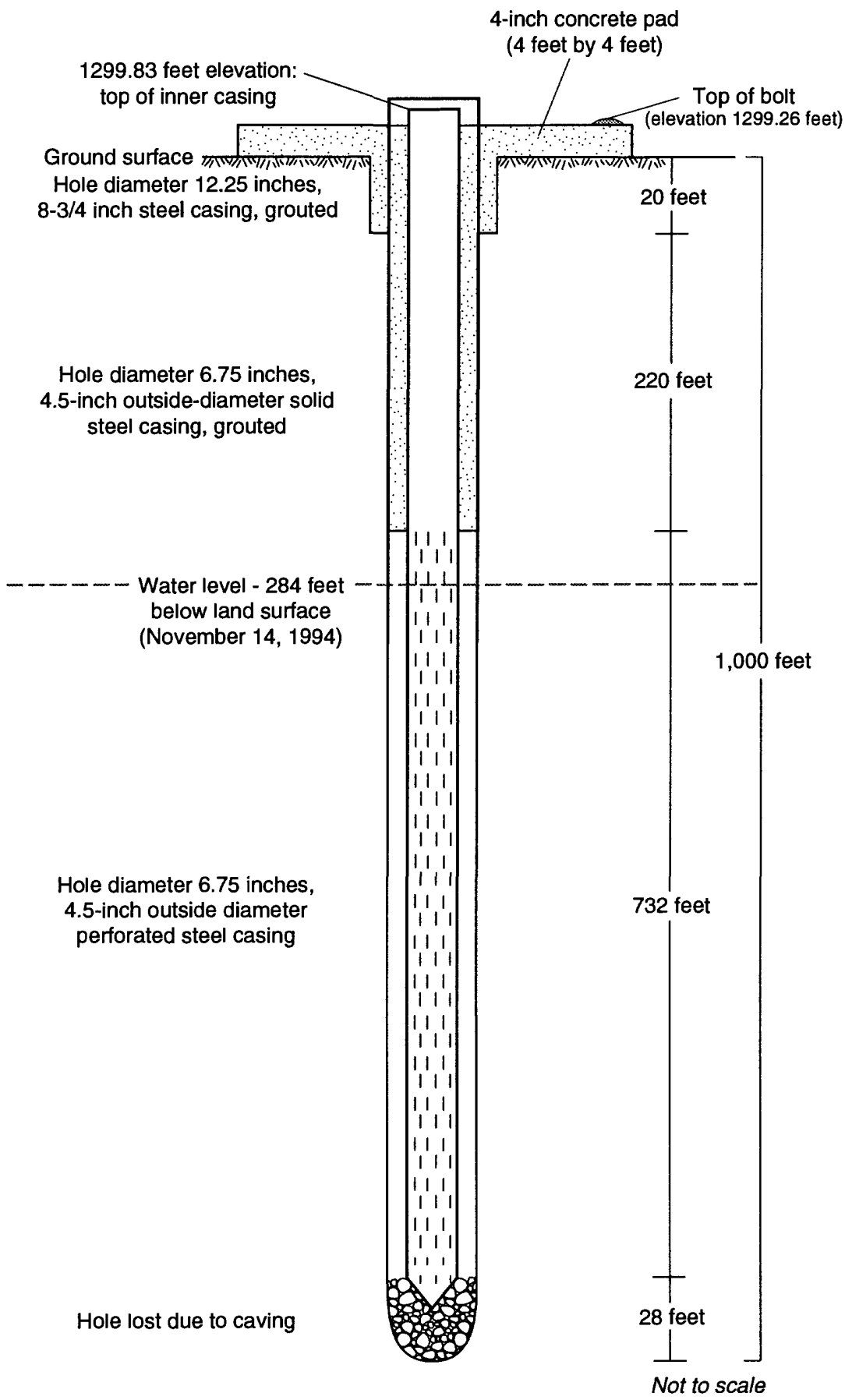

Figure 5. Construction details of the Waiohinu exploratory well (State well number 8-0437-01), island of Hawaii. 


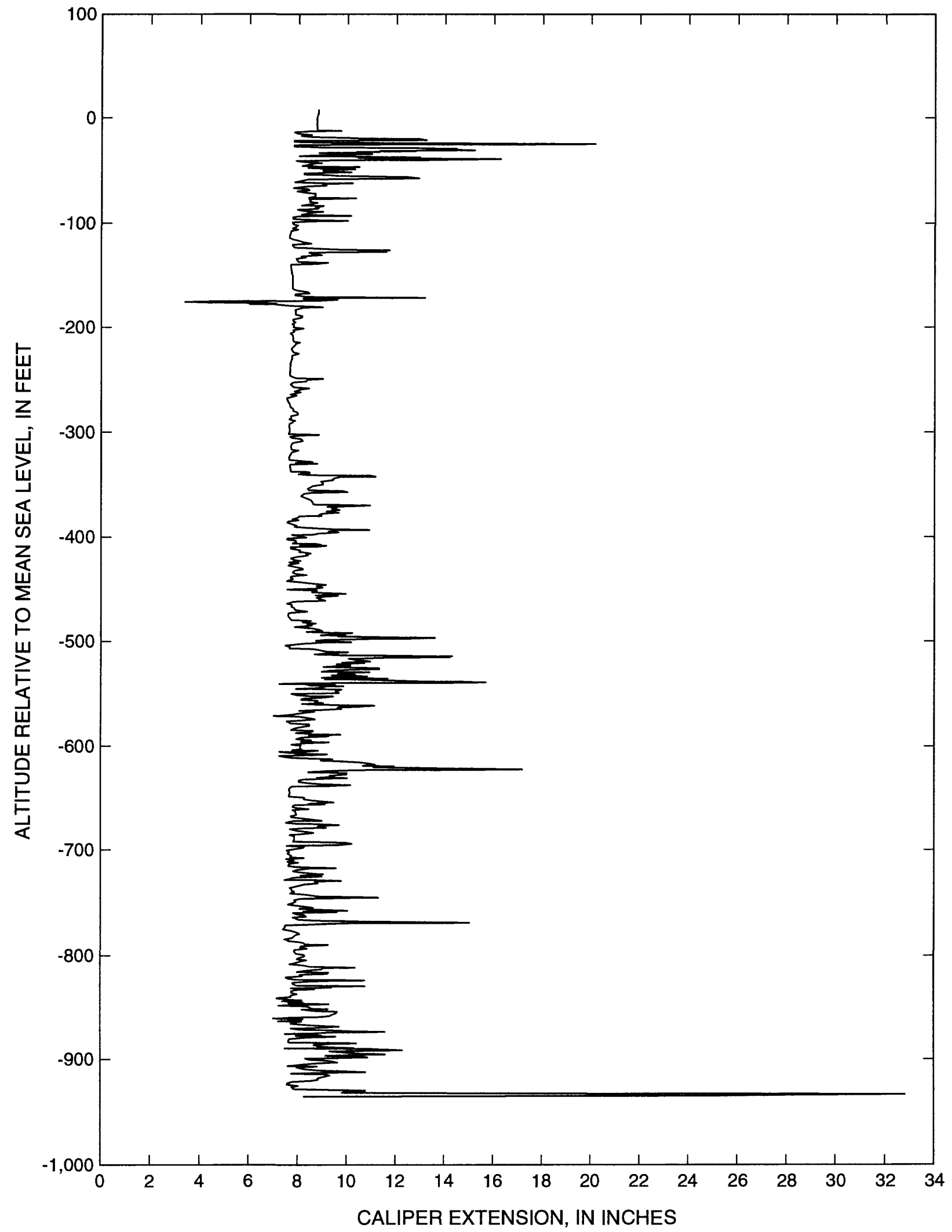

Figure 6. Caliper log for the Waiohinu exploratory well (State well number 8-0437-01), island of Hawaii. 
Table 3. Geologic log for Waiohinu exploratory well (State well number 8-0437-01), island of Hawaii

\begin{tabular}{|c|c|c|c|}
\hline \multicolumn{3}{|c|}{$\begin{array}{l}\text { Depth } \\
\text { (feet) }\end{array}$} & \multirow[b]{2}{*}{ light-gray highly vesicular clinker } \\
\hline 1 & to & 20 & \\
\hline 20 & to & 25 & no sample \\
\hline 25 & to & 30 & dark red-brown pebble size extremely vesicular basalt \\
\hline 30 & to & 35 & den light-gray some angular vesicles \\
\hline 35 & to & 40 & dark red-brown pebble size extremely vesicular basalt \\
\hline 40 & to & 45 & dark red-brown pebble size extremely vesicular basalt \\
\hline 45 & to & 50 & red-brown highly vesicular basalt with abundant olivine \\
\hline 50 & to & 55 & red-brown highly vesicular basalt with abundant olivine \\
\hline 55 & to & 370 & poor sample \\
\hline 370 & to & 474 & no sample \\
\hline 474 & to & 475 & large red-brown vesicular basalt clinker, angular vesicles \\
\hline 475 & to & 478 & few red-brown stained cuttings \\
\hline 478 & to & 484 & medium-gray dense basalt \\
\hline 484 & to & 495 & no sample \\
\hline 495 & to & 505 & mixture of pebble-cobble size basalt pieces, variable character, angular to subrounded, unweathered to moderately weathered \\
\hline 505 & to & 515 & mixture of pebble-cobble size basalt pieces, variable character, angular to subrounded, unweathered to moderately weathered \\
\hline 515 & to & 535 & mixture of pebble-cobble size basalt pieces, variable character, angular to subrounded, unweathered to moderately weathered \\
\hline 535 & to & 540 & mixture of pebble-cobble size basalt pieces, variable character, angular to subrounded, unweathered to moderately weathered \\
\hline 540 & to & 555 & mixture of pebble-cobble size basalt pieces, variable character, angular to subrounded, unweathered to moderately weathered \\
\hline 555 & to & 560 & mixture of pebble-cobble size basalt pieces, variable character, angular to subrounded, unweathered to moderately weathered \\
\hline 560 & to & 565 & mixture of pebble-cobble size basalt pieces, variable character, angular to subrounded, unweathered to moderately weathered \\
\hline 565 & to & 570 & mixture of pebble-cobble size basalt pieces, variable character, angular to subrounded, unweathered to moderately weathered \\
\hline 570 & to & 575 & mixture of pebble-cobble size basalt pieces, variable character, angular to subrounded, unweathered to moderately weathered \\
\hline 575 & to & 580 & mixture of pebble-cobble size basalt pieces, variable character, angular to subrounded, unweathered to moderately weathered \\
\hline 580 & to & 585 & mixture of pebble-cobble size basalt pieces, variable character, angular to subrounded, unweathered to moderately weathered \\
\hline 585 & to & 595 & mixture of pebble-cobble size basalt pieces, variable character, angular to subrounded, unweathered to moderately weathered \\
\hline 595 & to & 600 & mixture of pebble-cobble size basalt pieces, variable character, angular to subrounded, unweathered to moderately weathered \\
\hline 600 & to & 615 & red-brown clinker and dark-gray dense basalt with plagioclase phenocrysts \\
\hline 615 & to & 620 & $50 / 50$ mix red-brown clinker with dark-gray dense basalt with plagioclase phenocrysts \\
\hline 620 & to & 625 & dark-gray dense basalt with plagioclase phenocrysts \\
\hline 625 & to & 630 & mostly dark-gray dense basalt with plagioclase phenocrysts with clinker \\
\hline 630 & to & 635 & dark-gray to black to red-brown vesicular basalt \\
\hline 635 & to & 645 & gray to red-brown clinker \\
\hline 645 & to & 655 & dark-gray dense basalt with red-brown clinker \\
\hline 655 & to & 665 & dark-gray vesicular basalt with some red-brown clinker \\
\hline 665 & to & 675 & dark-gray vesicular basalt \\
\hline 675 & to & 680 & red-brown stained clinker with medium-gray dense basalt \\
\hline 680 & to & 690 & medium-gray dense basalt \\
\hline 690 & to & 695 & dark-gray dense basalt with red-brown clinker \\
\hline 695 & to & 700 & clinker \\
\hline 700 & to & 710 & medium-gray vesicular basalt with red-brown clinker \\
\hline 710 & to & 725 & medium-gray vesicular basalt with red-brown clinker \\
\hline 725 & to & 735 & dark-gray dense basalt with red-brown clinker \\
\hline 735 & to & 740 & dark-gray dense basalt \\
\hline 740 & to & 750 & dark-gray dense basalt with red-brown clinker \\
\hline 750 & to & 760 & gray dense basalt with vesicular red-brown clinker \\
\hline 760 & to & 770 & gray vesicular basalt with some dense basalt \\
\hline 770 & to & 775 & gray vesicular basalt with dark-gray clinker \\
\hline 775 & to & 790 & dark-gray dense basalt with plagioclase phenocrysts \\
\hline 790 & to & 795 & dark-gray dense basalt with plagioclase phenocrysts \\
\hline 795 & to & 800 & dark-gray dense basalt with plagioclase phenocrysts with some red-brown vesicular clinker \\
\hline 800 & to & 805 & no sample \\
\hline 805 & to & 815 & dark-gray dense basalt with plagioclase phenocrysts \\
\hline 815 & to & 825 & dark-gray vesicular basalt \\
\hline 825 & to & 835 & dark-gray vesicular basalt with medium-gray dense basalt \\
\hline 835 & to & 840 & medium-gray dense basalt \\
\hline
\end{tabular}


Table 3. Geologic log for Waiohinu exploratory well (State well number 8-0437-01), island of Hawaii--Continued

\begin{tabular}{|c|c|c|}
\hline \multicolumn{2}{|r|}{$\begin{array}{l}\text { Depth } \\
\text { (feet) }\end{array}$} & \multirow[b]{2}{*}{ medium-gray dense basalt } \\
\hline 840 & to 850 & \\
\hline 850 & 855 & no sample \\
\hline 855 & 860 & red-brown clinker with few dark-gray dense basalt pieces \\
\hline 860 & 865 & medium-gray dense basalt with some red-brown clinker \\
\hline 865 & 870 & medium-gray dense basalt \\
\hline 870 & 875 & medium-gray dense basalt \\
\hline 875 & 880 & medium-gray dense basalt with clinker \\
\hline 880 & 890 & gray dense basalt with red-brown clinker \\
\hline 890 & 900 & gray dense basalt with red-brown clinker \\
\hline 900 & 910 & gray dense basalt with red-brown clinker \\
\hline 910 & 915 & gray dense basalt \\
\hline 915 & 920 & gray dense basalt with red-brown clinker \\
\hline 920 & 925 & gray dense basalt with red-brown clinker \\
\hline 925 & 930 & gray dense basalt with red-brown vesicular basalt \\
\hline 930 & 935 & dark to medium-gray dense basalt with red-brown weathered vesicular basalt \\
\hline 935 & 940 & dark to medium-gray dense basalt with red-brown weathered vesicular basalt \\
\hline 940 & 950 & dark to medium-gray dense basalt with red-brown weathered vesicular basalt \\
\hline 950 & 965 & weathered to slightly weathered red-brown vesicular basalt \\
\hline 965 & 970 & weathered to slightly weathered red-brown vesicular basalt \\
\hline 970 & 975 & weathered to slightly weathered red-brown vesicular basalt \\
\hline 975 & 985 & weathered to slightly weathered red-brown vesicular basalt \\
\hline 985 & to 997 & weathered to slightly weathered red-brown vesicular basalt \\
\hline 997 & to 1,000 & slightly to moderately weathered, unconsolidated red-brown ash and lapilli \\
\hline
\end{tabular}

Notes: Samples collected by: G. Wayne Heick and Don Arnold

Sample type: Cuttings from rotary drilling with foam and polymer

Sample repository: U.S. Geological Survey, 677 Ala Moana Blvd. Suite 415, Honolulu, HI 96813

Geologic descriptions by: S.K. Izuka, U.S. Geological Survey

Date of logging: December 7-9, 1994 
Table 4. Driller's log for Waiohinu exploratory well (State well number 8-0437-01), island of Hawaii

[Drill crew--G. Wayne Heick, Don Arnold, Frederick Thibedeau; --, no measurement or not applicable; ${ }^{\circ} \mathrm{F}$, degrees Farenheit; ft, feet; in., inch]

\begin{tabular}{|c|c|c|c|c|}
\hline Date & Time & $\begin{array}{l}\text { Depth } \\
\text { (feet) }\end{array}$ & $\begin{array}{l}\text { Depth to } \\
\text { water } \\
\text { (feet) }\end{array}$ & Log/remarks \\
\hline \multirow[t]{16}{*}{$9 / 21 / 94$} & -- & $0-19$ & -- & Broken, loose blue rock aa \\
\hline & -- & $19-23$ & -- & Red cinders, soft, loose-caving problems cemented hole, re-drill \\
\hline & -- & $23-29$ & -- & Blue rock, soft, broken, fluid return \\
\hline & -- & $29-31$ & -- & Puka rock, clean, no cinders, good return \\
\hline & -- & $31-33$ & -- & Blue rock, medium soft, good return \\
\hline & -- & $33-37$ & -- & Red cinders, loose, soft, good return \\
\hline & -- & $37-39$ & -- & Blue rock, hard, good return \\
\hline & -- & $39-44$ & -- & Red clinkers, aa, very soft, fluid return \\
\hline & -- & $44-48$ & -- & Blue rock, hard, good return \\
\hline & -- & $48-50$ & -- & Red cinders, very loose, good return \\
\hline & -- & $50-54$ & -- & Blue rock, hard, good return \\
\hline & -- & $54-67$ & -- & Red cinders, very soft, lost circulation \\
\hline & -- & $67-72$ & -- & Blue rock, hard, no returns \\
\hline & -- & $72-77$ & -- & Red cinders, very broken, no return \\
\hline & -- & $77-80$ & -- & Blue rock, medium hard, no return \\
\hline & - & $80-95$ & -- & Red aa rock, medium soft, loose, broken \\
\hline \multirow[t]{7}{*}{$9 / 22 / 94$} & -- & $95-103$ & -- & Red aa rock, very soft, loose, no return \\
\hline & -- & $103-125$ & -- & $\begin{array}{l}\text { Blue rock, medium hard at } 103-112 \mathrm{ft} \text {, very hard at } 112 \mathrm{ft} \text {, solid no breaks, } \\
\text { no return }\end{array}$ \\
\hline & -- & $125-137$ & -- & Red aa, clinkers, loose, broken, rough going \\
\hline & -- & $137-150$ & -- & Blue rock, medium hard, uniform, no return \\
\hline & -- & $150-161$ & -- & Blue rock, very hard, slow drilling, no return \\
\hline & -- & $161-168$ & -- & Blue rock, medium hard, small breaks, no return \\
\hline & -- & $168-175$ & -- & Red, aa, medium soft, no return \\
\hline \multirow[t]{7}{*}{ 9/23/94 } & -- & $175-179$ & -- & Blue rock, medium hard, solid, no breaks \\
\hline & -- & $179-184$ & -- & Blue rock, aa, broken clinkers, no return \\
\hline & -- & $184-191$ & -- & Red, aa, soft, loose, no return \\
\hline & -- & $191-199$ & -- & Blue rock, medium hard, no return \\
\hline & -- & $199-258$ & -- & Blue rock, medium hard, smooth drilling, uniform \\
\hline & -- & $258-261$ & -- & Blue rock, hard, uniform, no return \\
\hline & -- & $261-270$ & -. & Blue rock, medium hard, uniform, no return \\
\hline \multirow[t]{2}{*}{$9 / 24 / 94$} & -- & $270-275$ & -- & Blue rock, medium hard, no return \\
\hline & -- & $275-305$ & -- & Red rock, aa?, medium hard, no return \\
\hline \multirow[t]{10}{*}{$9 / 25 / 94$} & -- & $305-329$ & -- & Red aa rock, some broken, no return \\
\hline & -- & $329-347$ & -- & Blue rock, hard, significant increase in air \\
\hline & -- & $347-360$ & -- & Red, aa rock, no returns, slight air increase \\
\hline & -- & $360-361$ & -- & Broken rock, loose, clinkers, some return with full air, possible water \\
\hline & -- & $361-365$ & -- & Red clinkers, bad zone, no return \\
\hline & -- & $365-369$ & -- & Blue rock, medium hard, smooth drilling \\
\hline & -- & $369-378$ & -- & Blue rock, hard, uniform, slow drilling, some fluid return \\
\hline & -- & $378-386$ & -- & Red broken rock, medium hard \\
\hline & -- & $386-390$ & -- & Blue rock, medium hard, drilling ok \\
\hline & -- & $390-452$ & -- & Red, fractured rock, aa?, some clinkers \\
\hline $9 / 26 / 94$ & -- & -- & -- & $\begin{array}{l}\text { Morning air test indicates } 130-150 \mathrm{ft} \text { of water in hole. Sounding indicates } \\
\text { water at about } 285 \mathrm{ft} \text {. Stripped drill tools out of hole finish by noon. Mea- } \\
\text { sure water level, depth to water } 284.82 \mathrm{ft} \text { at } 1300 \text { hours, prepare for pump } \\
\text { test. }\end{array}$ \\
\hline \multirow[t]{5}{*}{$9 / 26 / 94$} & 1300 & -- & 284.82 & Below top of casing \\
\hline & 1400 & -- & 284.82 & \\
\hline & 1500 & - & 284.82 & \\
\hline & 1600 & -- & 284.88 & \\
\hline & 1700 & -- & 284.90 & \\
\hline
\end{tabular}


Table 4. Driller's log for Waiohinu exploratory well (State well number 8-0437-01), island of Hawaii--Continued [Drill crew--G. Wayne Heick, Don Arnold, Frederick Thibedeau; --, no measurement or not applicable; ${ }^{\circ} \mathrm{F}$, degrees Farenheit; ft, feet; in., inch]

\begin{tabular}{|c|c|c|c|c|}
\hline Date & Time & $\begin{array}{l}\text { Depth } \\
\text { (feet) }\end{array}$ & $\begin{array}{l}\text { Depth to } \\
\text { water } \\
\text { (feet) }\end{array}$ & Log/remarks \\
\hline \multirow[t]{10}{*}{$9 / 27 / 94$} & 0800 & -- & 284.83 & \\
\hline & 0900 & -. & 284.83 & \\
\hline & 1000 & -- & 284.83 & \\
\hline & 1100 & -- & 284.83 & \\
\hline & 1200 & -- & 284.83 & \\
\hline & 1300 & -- & 284.83 & \\
\hline & 1430 & -- & 284.83 & \\
\hline & 1530 & -- & 284.83 & \\
\hline & 1630 & -- & 284.83 & \\
\hline & 1720 & -- & 284.83 & \\
\hline \multirow[t]{4}{*}{$9 / 28 / 94$} & 0800 & -- & 284.83 & \\
\hline & 0900 & -- & 284.83 & Built bailer for sampling \\
\hline & 1000 & -- & 284.83 & $\begin{array}{l}\text { Bailed one sample, } 12.5 \text { gallons, no depth to water change, water tempera- } \\
\text { ture } 62.2^{\circ} \mathrm{F} \text {, air temperature } 86.6^{\circ} \mathrm{F}\end{array}$ \\
\hline & 1300 & -- & -- & $\begin{array}{l}\text { Bailed } 6 \text { consecutive samples, about } 80 \text { gallons in } 30 \text { minutes, no change in } \\
\text { depth to water still at } 284.83 \text {. Water temperature } 62.2^{\circ} \mathrm{F} \text {, air temperature } \\
88.2^{\circ} \mathrm{F}\end{array}$ \\
\hline \multirow[t]{5}{*}{$10 / 3 / 94$} & 0800 & -- & 284.42 & $\begin{array}{l}\text { Ran one bailer sample, no water level change, water temperature } 62.4^{\circ} \mathrm{F} \text {, air } \\
\text { temperature } 86.4^{\circ} \mathrm{F}\end{array}$ \\
\hline & 1300 & -- & 284.40 & \\
\hline & 1400 &.- & 284.40 & \\
\hline & 1600 & -- & 284.40 & \\
\hline & & -- & & \\
\hline \multirow[t]{2}{*}{$10 / 4-7 / 94$} & -- & -- & -- & $\begin{array}{l}\text { Setting up generator, and drop pipe, routine maintenance, awaiting arrival of } \\
4 \text {-in. submersible pump }\end{array}$ \\
\hline & & -- & & \\
\hline \multirow[t]{2}{*}{$10 / 8-9 / 94$} & -- & -- & -- & Installing pump, control box, test generator \\
\hline & & -- & & \\
\hline $10 / 9-13 / 94$ & -- & -- & -- & Ran 92-hour pump test \\
\hline $10 / 17 / 94$ & -- & -- & -- & Drill crew on Oahu getting equipment \\
\hline $10 / 18 / 94$ & -- & -- & -- & Drill crew on site, remove well head, hoses, begin to pull pump \\
\hline \multirow{4}{*}{$10 / 19 / 94$} & -- & & & Resume drilling \\
\hline & -- & $452-466$ & -- & Red, aa?, broken medium soft, no return \\
\hline & -- & $466-472$ & -- & Blue rock, hard, no return, added foam \\
\hline & -- & $472-495$ & -- & Red, weathered aa, soft, broken, good return \\
\hline \multirow[t]{12}{*}{$10 / 20 / 94$} & -- & $495-540$ & $\ldots$ & Red, weathered aa, loose, good return \\
\hline & -- & $540-553$ & -- & Blue rock, medium soft, broken, good return \\
\hline & -- & $553-585$ & -- & Red, weathered rock, soft, broken good return \\
\hline & -- & $585-588$ & 284.15 & Blue rock, medium hard, broken, good return \\
\hline & -- & $588-594$ & -- & Blue-red rock, medium hard, good return \\
\hline & -- & $594-600$ & -- & Blue rock, medium hard, broken, good return \\
\hline & -- & $600-615$ & -- & Red-blue rock, clinker type, good return \\
\hline & -- & $615-627$ & -- & Blue rock, soft, water increase, good return \\
\hline & -- & $627-647$ & -- & Red weathered rock, soft, loose, clinkers \\
\hline & -- & $647-675$ & -- & Blue rock, medium soft, broken, good return \\
\hline & -- & $675-680$ & -- & Red weathered rock, soft, clinkers, return okay \\
\hline & -- & $680-692$ & -- & Blue rock, pahoehoe? medium hard, good return \\
\hline \multirow[t]{7}{*}{$10 / 21 / 94$} & -- & $692-720$ & -- & Blue rock, broken, more water, good return \\
\hline & -- & $720-728$ & -- & Blue rock, medium hard, uniform, good return \\
\hline & -- & $728-733$ & -- & Red, weathered rock, soft, loose, returns okay \\
\hline & -- & $733-740$ & 284.05 & Blue rock, solid, medium hard, good return \\
\hline & -- & $740-760$ & -- & Red rock, loose broken, bad zone, return okay \\
\hline & -- & $760-775$ & -- & Blue rock, broken, loose, more water \\
\hline & -- & $775-800$ & -- & Blue rock, medium hard, uniform, good return \\
\hline
\end{tabular}


Table 4. Driller's log for Waiohinu exploratory well (State well number 8-0437-01), island of Hawaii--Continued

[Drill crew--G. Wayne Heick, Don Arnold, Frederick Thibedeau; --, no measurement or not applicable; ${ }^{\circ} \mathrm{F}$, degrees Farenheit; ft, feet; in., inch]

\begin{tabular}{|c|c|c|c|c|}
\hline Date & Time & $\begin{array}{l}\text { Depth } \\
\text { (feet) }\end{array}$ & $\begin{array}{l}\text { Depth to } \\
\text { water } \\
\text { (feet) }\end{array}$ & Log/remarks \\
\hline \multirow[t]{19}{*}{$10 / 22 / 94$} & -- & $800-808$ & -- & Blue rock, medium hard, good return \\
\hline & -- & $808-825$ & -- & Red clinkers, soft, good return \\
\hline & -- & $825-833$ & -- & Blue rock, medium hard, uniform, return okay \\
\hline & -- & $833-843$ & 284.09 & Blue rock, medium soft, more water, return okay \\
\hline & -- & $843-860$ & -- & Red and black clinkers, very broken, big pieces \\
\hline & -- & $860-870$ & -- & Blue rock, broken, med, good return \\
\hline & $\cdots$ & $870-872$ & -- & Red cinders, uniform soft, more water \\
\hline & -. & $872-887$ & -- & Blue rock, medium hard, uniform, good return \\
\hline & -- & $887-897$ & -- & Blue-red rock mix, uniform, return ok \\
\hline & -- & $897-920$ & -- & Red weathered rock, soft, broken, return okay \\
\hline & -- & $920-925$ & -. & Blue rock, medium hard, uniform, return good \\
\hline & -- & $925-935$ & -- & Red-black ash-cinders, very soft, caving \\
\hline & -- & $935-948$ & -- & Red rock, loose, unstable, good return \\
\hline & - & $948-950$ & -- & Cinders, very broken, unstable, good return \\
\hline & -- & $950-952$ & -- & Blue rock, medium hard, good return \\
\hline & $\ldots$ & $952-975$ & -- & Red aa rock, soft, broken, loose, return okay \\
\hline & -- & $975-985$ & -- & Blue rock, medium hard, broken, good return \\
\hline & -- & 985-997 & -- & Black-red cinders or ash, very dense, caving \\
\hline & -- & $997-1,000$ & -- & Blue rock, medium hard, good return \\
\hline $10 / 23 / 94$ & -. & -- & -- & Drilling completed, final depth $1,000 \mathrm{ft}$ \\
\hline
\end{tabular}


Table 5. Aquifer-test data for Waiohinu exploratory well, State well number 8-0437-01, island of Hawaii

[Aquifer test began at 1600 hours on October 9, 1994 and terminated at 1200 hours on October 13, 1994. Length of test 92 hours.

Note: All water samples had a chloride concentration of less than 10 milligrams per liter as determined by Hach Kit analysis; gal, gallons; gal/min, gallons per minute; ${ }^{\circ} \mathrm{C}$, degrees Celsius; $\mu \mathrm{S} / \mathrm{cm}$, microsiemens per centimeter at $25^{\circ} \mathrm{C}$; --, no measurement or not applicable; WQ, water quality; gal, gallons]

\begin{tabular}{|c|c|c|c|c|c|c|c|c|}
\hline Date & Time & $\begin{array}{l}\text { Depth to } \\
\text { water } \\
\text { (feet) }\end{array}$ & $\begin{array}{c}\text { Drawdown } \\
\text { (feet) }\end{array}$ & $\begin{array}{c}\text { Elapsed } \\
\text { time } \\
\text { (minutes) }\end{array}$ & $\begin{array}{l}\text { Pumping } \\
\text { rate } \\
\text { (gal/min) }\end{array}$ & $\begin{array}{c}\text { Temperature } \\
\left({ }^{\circ} \mathrm{C}\right)\end{array}$ & $\begin{array}{c}\text { Specific } \\
\text { conductance } \\
(\mu \mathrm{S} / \mathrm{cm})\end{array}$ & Remarks ${ }^{2}$ \\
\hline \multirow[t]{34}{*}{$10 / 9 / 94$} & 1240 & 287.10 & -- & -- & $-\cdot$ & 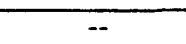 & -- & meter $00000 \mathrm{gal}$ \\
\hline & 1400 & 287.08 & -- & -- & -- & -- & -- & \\
\hline & 1530 & 287.07 & -- & -- & -- & -- & -- & \\
\hline & 1545 & 287.09 & -- & -- & -- & -- & -- & \\
\hline & 1600 & 287.09 & -- & -- & -- & -- & -- & Pump on \\
\hline & & 287.21 & 0.12 & 0.5 & -- & -- & -- & \\
\hline & & 287.26 & 0.17 & 1 & -- & -- & -- & \\
\hline & & 287.26 & 0.17 & 2 & -- & -- & -- & \\
\hline & & 287.26 & 0.17 & 3 & -- & -- & -- & \\
\hline & & 287.26 & 0.17 & 4 & -- & -- & -- & \\
\hline & & 287.27 & 0.18 & 5 & 61.5 & -- & -- & water clear \\
\hline & & 287.27 & 0.18 & 6 & -- & -- & -- & \\
\hline & & 287.27 & 0.18 & 7 & -- & -- & -- & \\
\hline & & 287.27 & 0.18 & 8 & -- & -- & -- & \\
\hline & & 287.27 & 0.18 & 9 & -- & -- & -- & \\
\hline & & 287.27 & 0.18 & 10 & 61.5 & -- & -- & \\
\hline & & 287.28 & 0.19 & 15 & -- & 17.9 & 85.9 & WQ sample 1 \\
\hline & & 287.28 & 0.19 & 20 & 61.5 & -- & -- & \\
\hline & & 287.28 & 0.19 & 25 & -- & -- & -- & \\
\hline & & 287.28 & 0.19 & 30 & 61.5 & -- & -- & \\
\hline & & 287.29 & 0.20 & 35 & -- & -- & -- & \\
\hline & & 287.28 & 0.19 & 40 & 60 & -- & -- & \\
\hline & & 287.29 & 0.20 & 45 & -- & -- & -- & \\
\hline & & 287.29 & 0.20 & 50 & 61 & -- & -- & \\
\hline & & 287.29 & 0.20 & 55 & -- & -- & -- & \\
\hline & 1700 & 287.28 & 0.19 & 60 & 60 & -- & -- & \\
\hline & 1715 & 287.30 & 0.21 & 75 & -- & -- & -- & \\
\hline & 1730 & 287.30 & 0.21 & 90 & 61 & 17.4 & 85.9 & $\begin{array}{l}\text { WQ sample } 2 \\
\text { meter } 7,327 \text { gal }\end{array}$ \\
\hline & 1745 & 287.29 & 0.20 & 105 & 61 & -- &.- & \\
\hline & 1800 & 287.30 & 0.21 & 120 & 62 & -- & -- & \\
\hline & 1830 & 287.30 & 0.21 & 150 & -- & -- & -- & \\
\hline & 2000 & 287.31 & 0.22 & 240 & -- & -- & -- & \\
\hline & 2030 & 287.31 & 0.22 & 270 & 61 & 17.5 & 87.3 & \\
\hline & 2100 & 287.31 & 0.22 & 300 & 61.5 & 17.4 & 87.4 & $\begin{array}{l}\text { WQ sample } 3 \\
\text { meter } 18,326 \text { gal }\end{array}$ \\
\hline \multirow[t]{14}{*}{$10 / 10 / 94$} & 0530 & 287.34 & 0.25 & 810 & 62 & 17.5 & 87.8 & \\
\hline & 0600 & 287.32 & 0.23 & 840 & -- & 17.4 & 87.9 & $\begin{array}{l}\text { WQ sample } 4 \\
\text { meter } 51,441 \text { gal }\end{array}$ \\
\hline & 0630 & 287.32 & 0.23 & 870 & 62 & -- & -- & \\
\hline & 0830 & 287.32 & 0.23 & 990 & 61 & -- & -- & \\
\hline & 0900 & 287.31 & 0.22 & 1020 & & 17.7 & 87.5 & meter $62,480 \mathrm{gal}$ \\
\hline & 1000 & 287.32 & 0.23 & 1080 & -- & -- & -- & \\
\hline & 1400 & 287.33 & 0.24 & 1320 & & 17.6 & 87.9 & meter $80,858 \mathrm{gal}$ \\
\hline & 1530 & 287.37 & 0.28 & 1410 & 61.5 & -- & -- & \\
\hline & 1600 & 287.40 & 0.31 & 1440 & & 17.5 & 88.2 & meter $88,210 \mathrm{gal}$ \\
\hline & 1630 & 287.40 & 0.31 & 1470 & -- & - & -- & \\
\hline & 1700 & 287.41 & 0.32 & 1500 & 61.5 & 17.4 & 88.0 & \\
\hline & 1730 & 287.40 & 0.31 & 1530 & -- & -- & -- & \\
\hline & 1800 & 287.40 & 0.31 & 1560 & -- & -- & -- & \\
\hline & 2000 & 287.40 & 0.31 & 1680 & 62 & 17.5 & 88.3 & meter $102,916 \mathrm{gal}$ \\
\hline
\end{tabular}


Table 5. Aquifer-test data for Waiohinu exploratory well, State well number 8-0437-01, island of Hawaii--Continued [Aquifer test began at 1600 hours on October 9, 1994 and terminated at 1200 hours on October 13, 1994. Length of test 92 hours. Note: All water samples had a chloride concentration of less than 10 milligrams per liter as determined by Hach Kit analysis; gal, gallons; gal/min, gallons per minute; ${ }^{\circ} \mathrm{C}$, degrees Celsius; $\mu \mathrm{S} / \mathrm{cm}$, microsiemens per centimeter at $25^{\circ} \mathrm{C}$; --, no measurement or not applicable; WQ, water quality; gal, gallons]

\begin{tabular}{|c|c|c|c|c|c|c|c|c|}
\hline Date & Time & $\begin{array}{l}\text { Depth to } \\
\text { water } \\
\text { (feet) }\end{array}$ & $\begin{array}{l}\text { Drawdown } \\
\text { (feet) }\end{array}$ & $\begin{array}{c}\text { Elapsed } \\
\text { time } \\
\text { (minutes) }\end{array}$ & $\begin{array}{c}\text { Pumping } \\
\text { rate } \\
\text { (gal/min) }\end{array}$ & $\begin{array}{c}\text { Temperature } \\
\left({ }^{\circ} \mathrm{C}\right)\end{array}$ & $\begin{array}{c}\text { Specific } \\
\text { conductance } \\
(\mu \mathrm{S} / \mathrm{cm})\end{array}$ & Remarks $^{2}$ \\
\hline \multirow[t]{10}{*}{$10 / 11 / 94$} & 0600 & 287.40 & 0.31 & 2280 & 61 & 17.3 & 88.4 & meter $141,540 \mathrm{gal}$ \\
\hline & 0630 & 287.40 & 0.31 & 2310 & -- & -- & -- & \\
\hline & 0700 & 287.41 & 0.32 & 2340 & -- & -- & -- & \\
\hline & 0900 & 287.39 & 0.30 & 2460 & 61.5 & 17.4 & 88.3 & \\
\hline & 1000 & 287.40 & 0.31 & 2520 & -- & -- & -- & \\
\hline & 1100 & 287.40 & 0.31 & 2580 & 61.5 & 17.4 & 88.5 & meter $176,412 \mathrm{gal}$ \\
\hline & 1200 & 287.40 & 0.31 & 2640 & -- & - & -- & \\
\hline & 1600 & 287.41 & 0.32 & 2880 & 61.5 & 17.4 & 88.3 & \\
\hline & 1700 & 287.41 & 0.32 & 2940 & -- & $\ldots$ & -- & \\
\hline & 2200 & 287.41 & 0.32 & 3240 & 62 & 17.5 & 88.5 & \\
\hline \multirow[t]{7}{*}{$10 / 12 / 94$} & 0700 & 287.41 & 0.32 & 3780 & 62 & 17.5 & 88.5 & meter $231,778 \mathrm{gal}$ \\
\hline & 1000 & 287.41 & 0.32 & 3960 & -- & -- & -- & \\
\hline & 1200 & 287.41 & 0.32 & 4080 & -- & -- & -. & \\
\hline & 1500 & 287.42 & 0.33 & 4260 & 61.5 & 17.5 & 88.5 & $\begin{array}{l}\text { WQ sample } 5 \\
\text { meter } 260,851 \mathrm{gal}\end{array}$ \\
\hline & 1600 & 287.41 & 0.32 & 4320 & -- & -- & -- & \\
\hline & 1700 & 287.42 & 0.33 & 4380 & -- & -. & -- & \\
\hline & 2000 & 287.41 & 0.32 & 4560 & 61.5 & 17.4 & 88.6 & \\
\hline \multirow[t]{4}{*}{$10 / 13 / 94$} & 0700 & 287.41 & 0.32 & 5220 & 61.5 & 17.4 & 88.6 & \\
\hline & 1000 & 287.42 & 0.33 & 5400 & 60.5 & -- & -- & meter $330,513 \mathrm{gal}$ \\
\hline & 1100 & 287.41 & 0.32 & 5460 & -- & -- & -- & $\begin{array}{l}\text { WQ samples for lab } \\
\text { analysis obtained }\end{array}$ \\
\hline & 1200 & 287.41 & 0.32 & 5520 & -- & -- & -- & Pump off \\
\hline \multicolumn{9}{|c|}{ Recovery } \\
\hline \multirow[t]{11}{*}{$10 / 13 / 94$} & 1200.5 & 287.36 & 0.29 & 0.5 & -- & $\cdots$ & -- & \\
\hline & 1201 & 287.32 & 0.23 & 1 & -- & -- & -- & \\
\hline & & 287.24 & 0.15 & 2 & -- & -- & -- & \\
\hline & & 287.21 & 0.12 & 3 & -- & -- & -. & \\
\hline & & 287.19 & 0.10 & 4 & -- & -- & -- & \\
\hline & 1205 & 287.19 & 0.10 & 5 & -- & -- & -- & \\
\hline & & 287.17 & 0.08 & 10 & -- & _- & -- & \\
\hline & & 287.15 & 0.06 & 15 & -- & -- & -- & \\
\hline & 1220 & 287.13 & 0.04 & 20 & -- & -- & -- & \\
\hline & & 287.12 & 0.03 & 25 & -- & -- & -- & \\
\hline & 1230 & 287.12 & 0.03 & 30 & -- & -- & -- & \\
\hline
\end{tabular}


Table 6. Water-quality data for Waiohinu exploratory well, Waiohinu, Hawaii

$\left[\mu \mathrm{S} / \mathrm{cm}\right.$, microsiemens per centimeter; ${ }^{\circ} \mathrm{C}$, degrees Celsius; $\mathrm{mg} / \mathrm{L}$, milligrams per liter; $\mu \mathrm{g} / \mathrm{L}$, micrograms per liter; <, less than; samples obtained October 13 , 1994 at 1100 hours]

Property or constituent

Value

INORGANICS

Physical properties

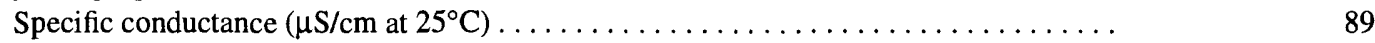

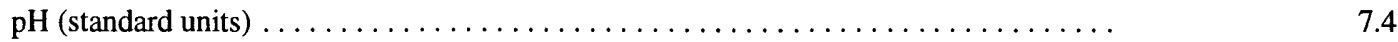

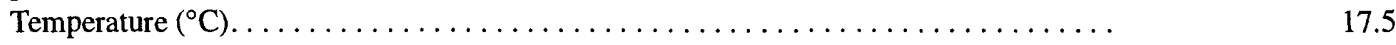

Dissolved solids, sum of constituents $(\mathrm{mg} / \mathrm{L}) \ldots \ldots \ldots \ldots \ldots \ldots \ldots \ldots \ldots \ldots \ldots$

\section{Major ions $(\mathrm{mg} / \mathrm{L})$}

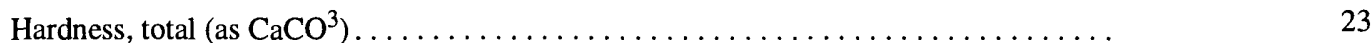

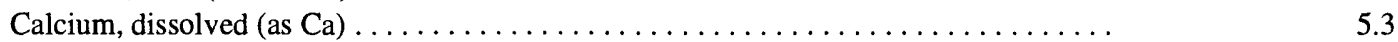

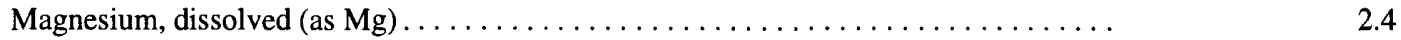

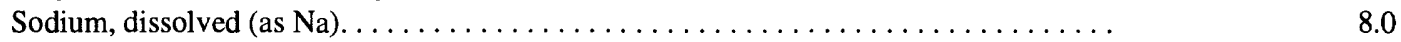

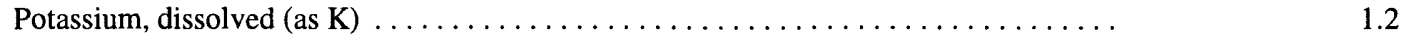

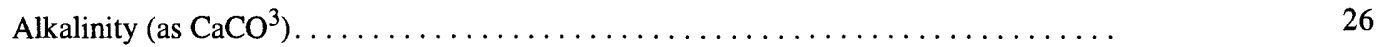

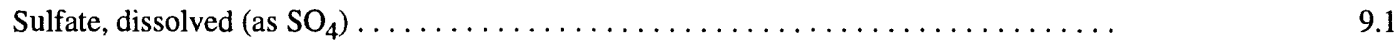

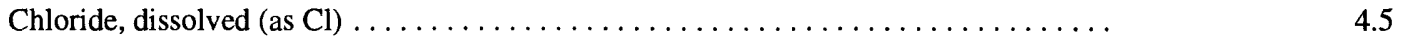

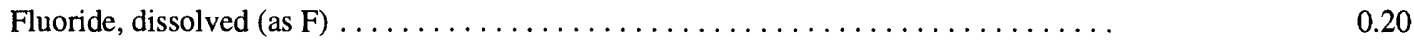

Silica, dissolved $\left(\right.$ as $\left.\mathrm{SiO}_{2}\right) \ldots \ldots \ldots \ldots \ldots \ldots \ldots \ldots \ldots \ldots \ldots \ldots \ldots \ldots \ldots \ldots$

Nutrients (mg/L)

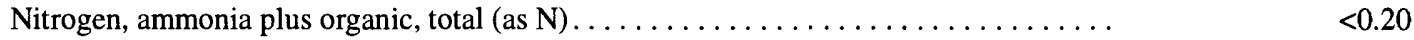

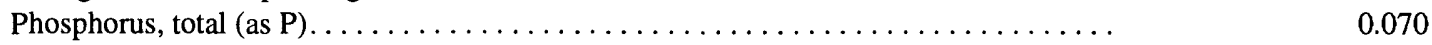

\section{Metals $(\mu \mathrm{g} / \mathrm{L})$}

Aluminum, total recoverable. . . . . . . . . . . . . . . . . . $\ldots \ldots \ldots \ldots \ldots . \ldots$

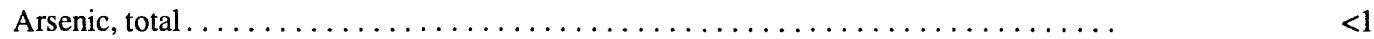

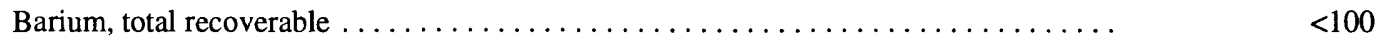

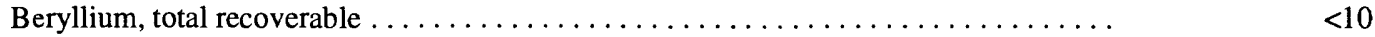

Cadmium, total recoverable $\ldots \ldots \ldots \ldots \ldots \ldots \ldots \ldots \ldots \ldots \ldots \ldots \ldots \ldots \ldots \ldots \ldots$

Chromium, total recoverable. . . . . . . . . . . . . . . . . . . . . . . . .

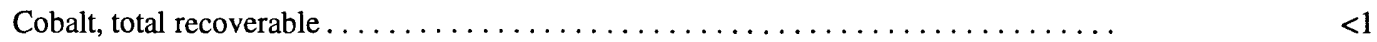

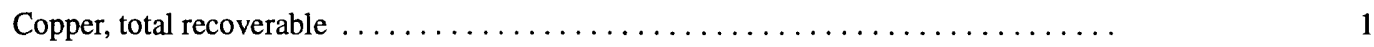

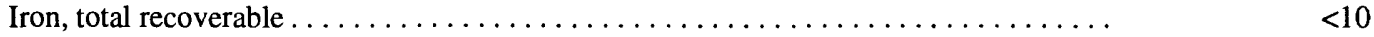

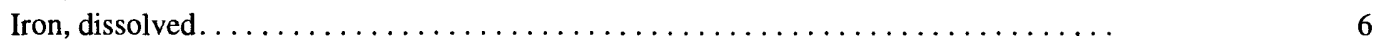

Lead, total recoverable $\ldots \ldots \ldots \ldots \ldots \ldots \ldots \ldots \ldots \ldots \ldots \ldots \ldots \ldots \ldots \ldots \ldots \ldots$

Lithium, total recoverable . . . . . . . . . . . . . . . . . $\ldots \ldots \ldots \ldots \ldots \ldots$

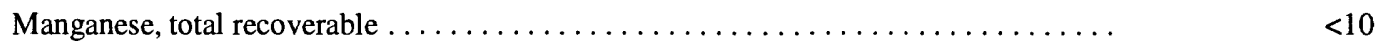

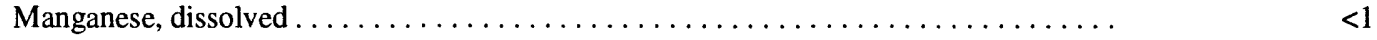

Mercury, total recoverable $\ldots \ldots \ldots \ldots \ldots \ldots \ldots \ldots \ldots \ldots \ldots \ldots \ldots \ldots \ldots \ldots \ldots . \ldots \ldots \ldots$

Molybdenum, total recoverable $\ldots \ldots \ldots \ldots \ldots \ldots \ldots \ldots \ldots \ldots \ldots \ldots \ldots \ldots \ldots . \ldots \ldots$

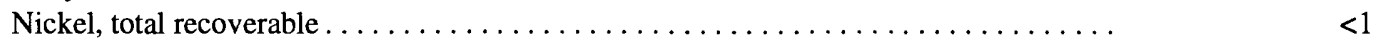

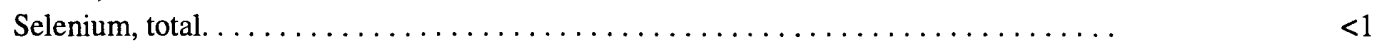

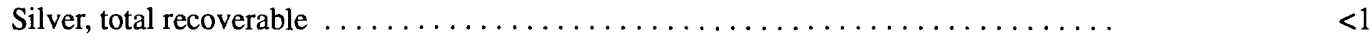

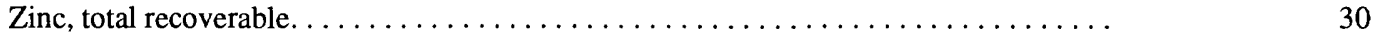

\section{ORGANICS}

Volatile organic compounds $(\mu \mathrm{g} / \mathrm{L})$

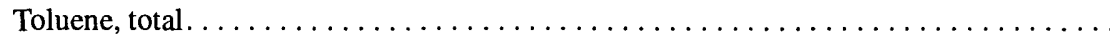


Table 6. Water-quality data for Waiohinu exploratory well, Waiohinu, Hawaii--Continued

$\left[\mu \mathrm{S} / \mathrm{cm}\right.$, microsiemens per centimeter; ${ }^{\circ} \mathrm{C}$, degrees Celsius; $\mathrm{mg} / \mathrm{L}$, milligrams per liter; $\mu \mathrm{g} / \mathrm{L}$, micrograms per liter; $<$, less than]

\begin{tabular}{|c|c|c|c|}
\hline \multicolumn{4}{|c|}{ Other organic compounds analyzed but were below reporting limits } \\
\hline Organic compound & $\begin{array}{l}\text { Reporting limit } \\
(\mu \mathrm{g} / L)\end{array}$ & Organic compound & $\begin{array}{c}\text { Reporting limit } \\
(\mathrm{mg} / \mathrm{L})\end{array}$ \\
\hline Alachlor $\ldots \ldots \ldots \ldots \ldots \ldots \ldots$ & $<0.05$ & Propazine $\ldots . \ldots \ldots \ldots$ & $<0.05$ \\
\hline Ametryn .......... & $<0.05$ & Silvex .......... & $<0.01$ \\
\hline Atrazine...$\ldots \ldots \ldots$ & $<0.05$ & Simazine.......... & $<0.05$ \\
\hline Benzene $\ldots \ldots \ldots \ldots \ldots \ldots$ & $<0.2$ & Styrene $\ldots \ldots \ldots \ldots \ldots \ldots$ & $<0.2$ \\
\hline Bromodichloromethane . & $<0.2$ & Tetrachloroethylene ........... & $<0.2$ \\
\hline Bromoform ............. & $<0.2$ & Trichloroethylene ........... & $<0.2$ \\
\hline Carbon tetrachloride.......... & $<0.2$ & Trichlorofluoromethane ........ & $<0.2$ \\
\hline Chlorobenzene ....... & $<0.20$ & Xylene ............... & $<0.20$ \\
\hline Chloroform.......... & $<0.2$ & $2,4-D \ldots \ldots \ldots \ldots \ldots$ & $<0.01$ \\
\hline cis-1,2-Dichloroethene . . . . . . & $<0.2$ & $2,4-D P \ldots \ldots \ldots \ldots \ldots \ldots \ldots$ & $<0.01$ \\
\hline Cyanazine ............... & $<0.20$ & 1,2-Dichlorobenzene $\ldots \ldots \ldots \ldots$ & $<0.20$ \\
\hline Deethylatrazine. .......... & $<0.05$ & 1,3-Dichlorobenzene $\ldots \ldots \ldots \ldots$ & $<0.20$ \\
\hline Deisopropylatrazin . . . . . . . . & $<0.05$ & 1,4-Dichlorobenzene $\ldots \ldots \ldots \ldots$ & $<0.20$ \\
\hline Dibromochloromethane ... & $<0.2$ & 1,1-Dichloroethane $\ldots \ldots \ldots \ldots$ & $<0.2$ \\
\hline Dichlorodifluoromethane ....... & $<0.2$ & 1,2-Dichloroethane. . . . . . . . & $<0.2$ \\
\hline Ethylbenzene $\ldots \ldots \ldots \ldots \ldots$ & $<0.2$ & 1,1-Dichloroethyl . . . . . . . . & $<0.2$ \\
\hline Methylene chloride. . . . . . . . . & $<0.2$ & 1,2-Dichloropropane. . . . . . . . & $<0.2$ \\
\hline Methyl tert-butyl ether . . . . . . . & $<0.2$ & $2,4,5-T \ldots \ldots \ldots \ldots \ldots \ldots \ldots$ & $<0.01$ \\
\hline Metolachlor. . . . . . . . . . & $<0.05$ & 1,2-Transdichloroethene. . . . . . & $<0.2$ \\
\hline Metribuzin sencor. .......... & $<0.05$ & 1,1,1-Trichloroethane $\ldots \ldots \ldots \ldots$ & $<0.2$ \\
\hline Prometon $\ldots \ldots \ldots$. & $<0.05$ & 1,1,2-Trichloro 1,2,2-trifluoroethane & $<0.2$ \\
\hline Prometryn $\ldots \ldots \ldots \ldots \ldots \ldots$ & $<0.05$ & & \\
\hline
\end{tabular}

Table 7. Water-quality data for samples collected during the aquifer test at Waiohinu exploratory well (State well number 8-0437-01), October 1994, island of Hawaii

[Chloride and silica concentrations obtained by use of Hach kit; --, no data]

\begin{tabular}{cccccc}
\hline $\begin{array}{c}\text { Sample no. } \\
\text { or place } \\
\text { (see table 5) }\end{array}$ & Date & Time & $\begin{array}{c}\text { Specific } \\
\text { conductance } \\
(\mu \text { S/cm) }\end{array}$ & $\begin{array}{c}\text { Chloride } \\
\text { concentration } \\
(\mathbf{m g} / \mathbf{L})\end{array}$ \\
\hline 1 & $10 / 9 / 94$ & 1615 & 85.9 & $<10$ & $\begin{array}{c}\text { Silica } \\
(\mathbf{m g} / \mathbf{L})\end{array}$ \\
2 & $10 / 9 / 94$ & 1730 & 85.9 & $<10$ & 40 \\
3 & $10 / 9 / 94$ & 2100 & 87.4 & $<10$ & -- \\
4 & $10 / 10 / 94$ & 0600 & 87.9 & $<10$ & -- \\
5 & $10 / 12 / 94$ & 1500 & 88.5 & $<10$ & 40 \\
\hline
\end{tabular}

